1 New evidence for a major late-Quaternary submarine landslide on the external western levee of Laurentian Fan

3 Alexandre Normandeau, D. Calvin Campbell, David J.W. Piper, Kimberley A. Jenner

Geological Survey of Canada (Atlantic), Natural Resources Canada, 1 Challenger Drive,

Dartmouth, Nova Scotia, Canada, B2Y 4A2

7 Abstract: The Laurentian Fan is one of the largest submarine fans on the western margin

8 of the North Atlantic. Recently acquired high-resolution multibeam bathymetric data (60

9 m horizontal resolution) reveal a major mass transport deposit (MTD) on the Western

10 Levee of Western Valley (WLWV), covering $>14000 \mathrm{~km}^{2}$ in water depths from $3900 \mathrm{~m}$

11 to $>5000 \mathrm{~m}$. Typical submarine landslide features are observed such as headscarps that in

12 places reach the crest of the levee, crown cracks, extensional ridges, blocky debris and flow

13 lineations. Multiple headwalls are observed on $3.5 \mathrm{kHz}$ sub-bottom profiles indicating that

14 the landslide retrogressed upslope. While the upper parts of the MTD consist of intact

15 blocks that were displaced downslope as ridges and troughs, the lower parts exhibit a $\sim 30$

16 m thick incoherent to transparent acoustic facies typical of debris flows. Landslide

17 geomorphology thus suggests that it was generated as a retrogressive spread and that slide

18 blocks disintegrated downslope to become a blocky landslide with a surficial debris flow.

19 The blocky landslide/debris flow extends downslope $\sim 90 \mathrm{~km}$ and partially fills a submarine

20 channel. The superposition of the MTD filling the channel and its location at the top of the

21 stratigraphic succession in the levee suggests that it is late Quaternary in age, possibly

22 Holocene. Deeper seismic reflection data also show that this is a rare event during the

23 Quaternary; it is the largest MTD observed in the upper $\sim 375 \mathrm{~m}$ of the levee succession

24 and among the largest and deepest in the Western North Atlantic.

\title{
25 Introduction
}

26 Submarine landslides play an important role in the evolution of active and passive margins

27 by transporting large volumes of sediment to the deep-sea. They commonly occur on steep

28 slopes, where sedimentary deposits are thick (Hampton et al. 1996). Submarine canyon 
29 environments are prime locations for the generation of landslides because they supply large

30 volumes of sediment and are characterized by steep slopes (e.g., Jenner et al., 2007).

31 Typically, landslides tend to be small and relatively frequent along canyon or channel

32 margins (e.g., Smith et al., 2005) whereas they are typically much larger and infrequent in

33 inter-canyon (or open) slopes (Lee, 2009).

34 Offshore Nova Scotia, large and infrequent submarine landslides have been reported on the

35 Scotian margin through the analysis of multibeam bathymetry and seismic stratigraphy

36 (e.g., Piper et al., 2003; Mosher et al., 2004). Landslide scars are widespread both on the

37 open slopes and on the inner canyon environments. The Laurentian Fan valleys, extending

38 from the Laurentian Channel, are no exception to the presence of submarine landslides. As

39 an example, they were the main conduits for the 1929 Grand Banks failure (Piper and Aksu,

40 1987; Piper et al., 1999). Because the fan valleys were fed by glacigenic sediments

41 originating from a large part of southeastern Canada throughout the Quaternary (Piper et

42 al. 2016), they host some of the largest levees in the world (Skene et al., 2002; Skene and

43 Piper, 2003). Levees are wedge-shaped sedimentary deposits formed by deposition along

44 the margin of channels that confine sediment density flows (Kane et al., 2010). Levees

45 consist mainly of an alternation of turbidites and hemipelagites and are often characterized

46 by sediment waves (Migeon et al., 2001). Landslides on levees are generally localized and

47 affect the inner levees, where the slope is steepest (e.g., Klaucke et al., 1997).

48 Canada is a signatory to the United Nations Convention on the Law of the Sea (UNCLOS);

49 as a result, significant efforts have been made to map its extended continental shelf during

50 the past decade. This systematic mapping has led to numerous discoveries on the seafloor,

51 many of them related to geohazards. A large mass-transport deposit (MTD) on the Western

52 Levee of Western Valley (WLWV), first recognized by Hughes-Clarke (1988) and Piper

53 (1991), was recently mapped as part of Canada's extended continental shelf program. The

54 extent of this MTD was previously unknown due to a lack of multibeam coverage and

55 seismic stratigraphy in the region. In a region as well studied as the Laurentian Fan, such

56 a large failure remained largely undocumented (Hughes-Clarke, 1988) and its significance

57 in the stratigraphic record unknown. 
58 In this paper, we document the slope failures on the WLWV of Laurentian Fan.

59 Specifically, this paper addresses: 1) the geomorphology of the WLWV as a depositional

60 and erosional environment; 2) the recurrence of submarine landslides in order to document

61 the importance of the major WLWV MTD on external levee growth; 3) the failure style of

62 this large MTD; and 4) its importance in the levee's stratigraphic record.

\section{Regional setting}

64 The Eastern Canadian continental shelf is characterized by the Laurentian Channel, a wide, 65 deep, glacially carved cross-shelf trough (Todd, 2016). Seaward of the Laurentian Channel 66 lies the large Quaternary Laurentian Fan (Piper, 2005). The Laurentian Fan is crossed by 67 the Eastern and Western valleys (Fig. 1). The Eastern Valley is a $40 \mathrm{~km}$-wide channel with 68 its head starting at a depth of $\sim 400 \mathrm{~m}$; the Western Valley is narrower $(\leq 20 \mathrm{~km})$. Both 69 valleys are connected by a narrow Central Valley that originates from a low point on the 70 Eastern Valley near $3000 \mathrm{~m}$ and joins the Western Valley near $3800 \mathrm{~m}$ (Fig. 1). The western

71 levees of both the Eastern and Western Valleys are among the largest in the World (Skene 72 et al. 2002).

73 The sedimentology and stratigraphy is well known in the study area (Mosher et al., 2004).

74 Proglacial sedimentation is characterized by grayish brown mud with silty turbidites and 75 ice-rafted debris overlain by red brown mud with sandy intervals and ice-rafted debris. The 76 late Quaternary stratigraphy of the Laurentian Fan reveals that turbidite deposition ceased 77 around $14 \mathrm{ka}{ }^{14} \mathrm{C} \mathrm{BP}$ (Skene and Piper, 2003). Brick red mud units linked with Heinrich 78 events were deposited in the upper parts of this red brown mud facies and are dated to 14$7913 \mathrm{ka}{ }^{14} \mathrm{C}$ BP. Holocene sedimentation is characterized by olive gray mud and silt, often 80 bioturbated.

81 MTDs occur on canyon walls (Jenner et al., 2007), and occasionally on open slopes 82 (Mosher et al., 2004). The largest MTDs are observed deeper in the stratigraphic record, 83 two of the largest ones being MTD-J and the $150 \mathrm{ka}$ BP MTD-D (Fig. 2A). They were 84 hypothesized to have been triggered by earthquakes and preconditioned by high glacial 85 sedimentation (Piper \& Ingram, 2003). 


\section{Methods}

87 Deep-water, high-resolution bathymetric data was collected by the Geological Survey of 88 Canada (GSC) and the Canadian Hydrographic Service (CHS) in 2012 on board the R/V 89 Atlantis (Expedition AT22-01) using a Hull mounted 12 kHz Kongsberg EM122 90 multibeam sonar coupled with a XYSEA PHINS integrated motion sensor. Positioning was 91 provided by a satellite corrected CNav GPS and real-time sound speed at the transducer 92 was acquired using a Seabird TSG velocity sounder. Expendable bathythermograph sound 93 speed profiler casts were recalculated using the 2009 World Ocean Atlas (WOA) database 94 salinity profiles and imported in real-time to the navigation and acquisition software (SIS). 95 The EM122 has a $64^{\circ}$ swath angle and 865 beams per ping. The data was imported into 96 Caris HIPS and SIPS and gridded at a $60 \mathrm{~m}$ resolution. Backscatter intensity information 97 was also recorded during the Atlantis cruise and was processed using Caris HIPS and SIPS 98 Geocoder engine. The data were gridded at a $40 \mathrm{~m}$ resolution but the resolution decreases 99 with increasing distance from nadir.

100 During the Atlantis cruise, $3.5 \mathrm{kHz}$ Knudsen sub-bottom profiler data were acquired along 101 the same lines as the multibeam data. These lines are roughly parallel to the depth contours, 102 limiting the analysis of downslope features. In 2016, a GSC expedition on CCGS Hudson 103 acquired seismic reflection data using a Huntec deep-tow system with a sparker source.

104 The acoustic output was centered on $\sim 1.5 \mathrm{kHz}$, with a $0.5-2.5 \mathrm{kHz}$ bandwidth. $3.4 \mathrm{~L}$ 105 Generator-Injector (GI) gun and single channel streamer data were collected to image 106 deeper reflections. The sub-bottom data were imported and analyzed in The Kingdom Suite 107 software.

\section{Results}

109 Morphology and internal architecture of the Western Levee of Western Valley

110 The WLWV has a relief, measured as the height above the floor of Western Valley, of 650 $111 \mathrm{~m}$ at $3500 \mathrm{~m}$ water depth. Its relief progressively decreases downslope to less than $100 \mathrm{~m}$ 112 at $>4700 \mathrm{~m}$ water depth (Fig. 1). The steep inner levee wall slope $\left(5-6^{\circ}\right)$ consists of 113 widespread and small scarps and gullies, even at depth of $>4500 \mathrm{~m}$ (Fig. 3). The eastern 114 inner levee wall also consists of headscarps, although they are less common than on the 
115 western one, where data are available. The headscarps do not appear to have a resulting

116 deposit downslope since the latter may have been remobilized by density flows that eroded 117 the Valley.

118 The external levee slope of WLWV has a much smoother surface compared to the inner

119 levee slope, with a mean gradient $\leq 1^{\circ}$. This smooth appearance is due to the lower relief

120 of the different geomorphological features observed. At a depth of $\sim 3500 \mathrm{~m}$, the levee is

121 composed of an aggradational spillover channel that has a $20 \mathrm{~km}$-wide head narrowing 122 downslope to $3 \mathrm{~km}$ (Fig. 3, 4A). The head of this channel is located near the confluence of 123 the Western and Central Valleys, where density flows likely overspill the levee.

124 Downslope, an unnamed channel delimits the western extent of the levee (Fig. 3).

125 The upper $0.2 \mathrm{~s}$ TWT of seismic profiles collected over the levee can be separated into two 126 distinct acoustic facies. The shallower undisturbed depths consist of generally continuous, 127 parallel medium to high-amplitude reflections (Fig. 4A) whereas the deeper areas of the 128 levee consist of discontinuous chaotic reflections (Fig. 4B). Wavy reflections observed in 129 the shallower parts of the levee result from the draping of underlying chaotic reflections.

130 Near the crest of the levee, the upper reflections, i.e., those at the seafloor, often appear 131 chaotic, reflecting small MTDs (Fig. 3A). Seismic reflections across the levee reveal that 132 the thickness of the sediment diminishes away from the valley, consistent with higher 133 sedimentation rates at the crest during levee growth (Fig. 2B).

134 Surficial mass transport deposit characteristics

135 The main surficial MTD (WLWV MTD) was mapped from the bathymetry and backscatter 136 imagery and has its shallowest headscarp at a water depth of $\sim 4000 \mathrm{~m}$ and extends down 137 to more than $5000 \mathrm{~m}$. Its basinward limit is unknown since the multibeam coverage ends 138 at a water depth of $5000 \mathrm{~m}$ (Fig. 3). The MTD is more than $100 \mathrm{~km}$ wide and extends 139 downslope approximately $100 \mathrm{~km}$ (run-out length), encompassing an area of $>14000 \mathrm{~km}^{2}$.

140 The headscarp of the landslide commonly reaches the crest of the levee; where it does not, 141 it is amphitheatre shaped, arcuate to elongate in plan form, and has crown cracks along the 142 headwalls (Fig. 5). The headscarps are 5-10 km wide and the scar slopes reach locally $10^{\circ}$ 143 but are typically $<5^{\circ}$, with heights of $\sim 40 \mathrm{~m}$. Its run-out ratio (headscarp height vs run-out 
144 length) is 0.0005 , making it a long running landslide relative to its height (McAdoo et al.,

145 2000). The adjacent undisturbed slopes are $\leq 1^{\circ}$. The proximal domain is characterized by 146 ridges and troughs spaced 300-400 m apart gradually increasing to more than $500 \mathrm{~m}$ (Fig.

147 5). The ridges and troughs morphology progressively disintegrate downslope into blocky 148 debris and then to a smooth seafloor with lineations. In some cases, the shallower parts of 149 the MTD have well-defined small lobe deposits that appear to overlie MTD sediments (lobe 150 superposition; Fig. 5). The ridges and troughs lack any seismic internal structures and are 151 chaotic. Where the headscarps reach the crest, ridges and troughs are absent and are 152 replaced by an extensive field of blocky debris (Figs. 4B-5).

153 The backscatter response of the undisturbed sediment on the levee is relatively low and can 154 be observed to the north (Fig. 6). The backscatter intensity increases substantially on the 155 MTD. The multibeam bathymetry, in combination with the backscatter imagery, reveals 156 the presence of flow lineations in a NE/SW direction. Downslope, these flow lineations 157 abruptly stop where the MTD partly fills the unnamed channel. This channel is the 158 westward limit of the MTD. The MTD is typically frontally confined since the unnamed 159 channel limits frontal emergence (Fig. 4B-2A). Where the MTD does not reach this 160 channel, frontal emergence is observed (Fig. 7A) and can easily be differentiated in the 161 backscatter imagery (Fig. 6).

162 The $3.5 \mathrm{kHz}$ acoustic stratigraphy reveals that the glide plane is a high-amplitude reflection 163 (Figs. 4B,7). It is generally continuous from the mid levee to the toe of the MTD (Fig. 4B). 164 Occasional erosional features, possibly grooves and erosional pits are observed (Fig. 7A). 165 Upslope, the acoustic appearance is very chaotic, reflecting the presence of blocky debris 166 near the crest of the levee. The thickness of the deposit is also more variable near the crest 167 of the levee, ranging between $10 \mathrm{~m}$ on steeper slopes and $30 \mathrm{~m}$ on lower slopes. Where 168 slopes are steeper, retrogressive headwalls are observed (Fig. 7B).

\section{Discussion}

\section{Landslide behaviour}

171 The landslide can be divided into three zones of different failure types (Figs 4, 5): 1) Zone 1721 is characterized by extensional spreading of the seabed; 2) Zone 2 is characterized by an 
173 extensive blocky debris field and; 3) Zone 3 consists of disintegrated blocks and likely

174 represents a complex slide with a debris flow overlying a blocky landslide.

175 The ridge and trough morphology is characteristic of spreads, a type of failure

176 characterized by the failure of sediment into coherent blocks displaced downslope along a

177 glide plane (e.g., Micallef et al., 2007; Baeten et al., 2013). The spreading component of

178 the MTD is confined to the amphitheater shaped scarps that did not reach the crest of the

179 levee. These cohesive blocks were displaced downslope along a planar gliding plane.

180 Spreading is also often indicative of headscarp retrogression, which is further observed by

181 the presence of multiple headwalls in the sub-bottom profiles (Fig. 7B). The spreading 182 retrogressed upslope and disintegrated downslope into a blocky debris MTD and finally 183 into a debris flow. The spreading component of the MTD is absent in some places because 184 the retrogression reached the crest of the levee and was completely evacuated as a blocky 185 landslide (Fig. 4B). Retrogression to the levee crest may indicate little change in upslope 186 sediment strength that would have been able to stop the retrogression. The possible 187 grooves, or at least local erosion of the glide plane (Fig. 7A), indicate that large intact 188 blocks within the blocky MTD eroded the seabed during downslope movement or that the 189 glide plane was not confined to a single stratigraphic level. Such intact blocks are not 190 observed on the sub-bottom data, perhaps because of the large acoustic footprint making it 191 impossible to resolve such features or because they disintegrated following the localized 192 erosion of the glide plane. The debris flow extends down the flank of the external levee, 193 eventually terminating in an unnamed channel that runs parallel to Western Valley (Fig. 194 2). To the south, away from this unnamed channel, the MTD displays frontally emergent 195 characteristics, that is, the deposit ramps up from its original basal shear surface (Frey196 Martinez et al., 2006) (Fig. 6-7A).

197 The upslope spreading zone likely formed in two ways: 1) it could have resulted from the 198 initial development of the large landslide during one main event with rapid retrogression 199 of the headscarp; or 2) it could have formed following an initial phase of mass transport 200 during multiple and distinct events. The sliding of material downslope can cause a loss of 201 support for the upslope sediment, which can be reactivated during a later, distinct trigger 202 event. There is also evidence from lobe superimposition that evacuation of the main MTD 
203 led to a loss of support in the upslope part of the levees, which could have caused upslope 204 spreading (Fig. 5).

205 In any case, the blocky debris flow is likely the result of disintegration of an initial spread.

206 The blocks at the distal edge of the spread were displaced downslope and disintegrated 207 when passing over the pre-existing headwalls (e.g., Piper et al., 1999; Micallef et al., 2007).

208 This process is illustrated in Fig. 7B where a blocky debris field thins over a steeper slope 209 with buried retrogressive headwalls and thickens as a homogeneous acoustic unit 210 downslope. The $3.5 \mathrm{kHz}$ consistently reveals incoherent acoustic reflections within the

211 deposit, suggesting disintegration of the failed deposit and its homogenization during 212 transport. These surficial sediments broke up easily during transport because of the 213 presence of thin sand and silt turbidites that shear during downslope movement (Piper et 214 al., 2012).

\section{Timing of submarine landslides}

216 Landslides on the internal slope of the WLWV are suspected to have occurred frequently 217 during the Pleistocene according to the number of landslide scarps visible on the multibeam 218 imagery. The presence of these landslides is also consistent with the frequent passage of 219 sediment density flows in the channel during the glacial period (Skene and Piper, 2003) 220 which caused erosion, undercutting and oversteepening of the channel wall. However, 221 landslides are comparatively infrequent on the lower gradients $\left(<1^{\circ}\right)$ of the external levee.

222 Small landslides are present near the crest of the levee but long-running ones reaching the 223 base of slope are infrequent (Fig. 2B). The most recent MTD appears to be the largest on 224 the levee.

225 Piper (1991) initially suggested that the largest landslide on the WLWV was triggered 226 during the Holocene solely based on its presence in the upper stratigraphic succession. The 227 high-resolution imagery presented here provides additional support for a late-Pleistocene / 228 Holocene age of the MTD. The debris flow component of the MTD extends $\sim 90 \mathrm{~km}$ 229 downslope and partially fills an unnamed submarine channel. The filling of the channel 230 and the location of the MTD at the top of the stratigraphic succession on the levee suggests 231 that it occurred after major canyon flow events ceased and is possibly post-glacial in age. 
232 The major gravity flows in submarine canyons along the Scotian margin have been active

233 until $\mathrm{ca} 14 \mathrm{ka}^{14} \mathrm{C} \mathrm{BP}$ (Skene and Piper, 2003), which suggests that turbidity currents would

234 have eroded/altered the MTD if it had been triggered prior to deglaciation.

235 Although the main event most likely occurred during the late-Pleistocene / Holocene, 236 smaller components of the landslide may have occurred more recently. Evidence of smaller 237 landslide activity following the main event is observed near the crest of the levee. For 238 example, a deposit appears to overlie the main blocky MTD (Fig. 5). Additionally, the 239 presence of crown cracks suggests that the landslide may not be in a stable state. Crown 240 cracks typically indicate incipient failure that could be ongoing in the region (e.g., Micallef 241 et al., 2007; Li et al., 2016). Therefore, although the main landslide may have been 242 triggered during the late Pleistocene or early Holocene, it could have been reactivated 243 locally after the initial failure.

\section{Significance in the stratigraphic record and geohazard implications}

245 A large MTD on the WLWV was first identified by Hughes-Clarke (1988) and Piper 246 (1991) based on sparse echosounder profiles. At the time, its submarine extent, 247 geomorphology and importance in the stratigraphic record was unclear due to lack of data. 248 The newly acquired multibeam bathymetric data allows us to identify it as one of the largest 249 MTDs observed in the Western North Atlantic with an area of $>14000 \mathrm{~km}^{2}$. According to 250 Lee et al. (2007), only $2 \%$ of the landslides on the United States margin have an area larger 251 than $1000 \mathrm{~km}^{2}$ and the largest is estimated at $19000 \mathrm{~km}^{2}$. On the Canadian margin, it is the 252 largest surficial landslide identified to date although larger landslides were identified in the 253 stratigraphic record, namely the $\sim 93000 \mathrm{~km}^{2}$ Montagnais landslide (Deptuck and 254 Campbell, 2012). In the North Atlantic, this landslide is also among the deepest at $4000 \mathrm{~m}$ 255 (Huhnerbach and Masson, 2004). Most landslides on the Scotian margin were initiated on 256 the upper slope and evolved on the lower slope. The WLWV landslide initiated on the 257 lower Scotian Slope and still led to one of the largest MTD in the region. Its presence in 258 deep-water and on low angle slopes, its size and its young age make it a significant event 259 to have occurred in the North Atlantic. 
260 Small MTDs are recognized on the external levee of WLWV but are generally restricted

261 to its upper parts. On the other hand, extensive MTDs disturbing the entire external levee 262 appear to be extremely rare in the stratigraphic record. Deep seismic reflection data show 263 that during the Quaternary, the shallowest MTD is also the largest one observed in the 264 upper $\sim 375 \mathrm{~m}$ of the levee succession. In the stratigraphic record of the Nova Scotia 265 continental slope, the WLWV MTD is among the largest reported. Piper and Ingram (2003) 266 described a series of Quaternary sediment failures on the east lower Scotian Slope, the 267 largest, MTD-D (Fig. 4B), estimated to have occurred at $\sim 150 \mathrm{ka} \mathrm{BP}$. These MTDs were 268 described as originating from the continental slope. The known extent of MTD-D is $\sim 8$ $269000 \mathrm{~km}^{2}$. However, the new seismic profiles show that the areal extent of MTD-D may be 270 two times greater. Therefore, in terms of areal extent, MTD-D and the WLWV MTD are 271 similar. The volumes of failure are likely different since Fig. 2A clearly shows that MTD272 D is much thicker than WLWV MTD. The volume of sediment involved in MTD-D is 273 estimated at $800 \mathrm{~km}^{3}$ whereas the volume of sediment involved in WLWV MTD is 274 estimated at $300-400 \mathrm{~km}^{3}$. Nonetheless, the WLWV MTD is the largest late-Pleistocene / 275 Holocene MTD on the Scotian margin identified to date, making it much younger than the 276 ones described by Piper and Ingram (2003). It also remobilized a much larger volume than 277 the 1929 earthquake-induced turbidite, the latter involving $150 \mathrm{~km}^{3}$ of failed material 278 (Piper and Aksu, 1987). This giant landslide is thus a significant event in the late 279 Quaternary record of the Scotian Slope.

280 Most landslides on the Scotian margin are believed to have been triggered by earthquakes 281 (Piper and McCall, 2003). In this particular case, the earthquake trigger appears likely since 282 two coeval MTDs are observed on the levee (Fig. 3). Unique geological setting may also 283 be partly responsible for this event since it is located on one of the largest levees in the 284 world, an emplacement that differs from other large MTDs. External levees are typically 285 characterized by sediment waves with little evidence of MTDs (e.g., Migeon et al., 2001), 286 which are generally observed on the inner levee walls. However, it is worth noting that the 287 large accumulation of sediments on the levee as well as the alternation of hemipelagites 288 and turbidites favour the presence of weak layers (Cauchon-Voyer et al. 2008) which in 289 turn favour the occurrence of landslides. In this respect, levee MTDs are similar to 
290 contourite drifts where failures may be due to low shear strength owing to high

291 sedimentation rates and well sorted sediment, underconsolidation, and loading due to 292 earthquakes and overlying sediment (Laberg and Camerlenghi, 2008). Although

293 earthquakes are rare in the region, they do occur preferentially along the Laurentian Fan

294 region, most notably being the M7.2 1929 event (Mazzotti, 2007). Other earthquakes may

295 have occurred during the Holocene (e.g., Piper et al., 1985) but are insufficiently

296 documented at present.

\section{Conclusion}

298 Recently-acquired multibeam bathymetry data expose the presence of one of the most 299 extensive MTDs in the Western North Atlantic, covering an area of $>14000 \mathrm{~km}^{2}$. The 300 results from this study reveal that:

301 1) The landslide initiated as a retrogressive spread that rapidly evolved downslope as 302 a blocky debris landslide. The retrogression reached the crest of the levee in a large part of the region, leading to its disintegration as a debris flow;

2) The MTD filled an unnamed channel downslope and is located at the top of the stratigraphic succession, suggesting it is late-Pleistocene to Holocene in age, making it one of the most recent major landslides on the Scotian Slope;

3) The presence of multiple headwalls and lobe superimposition suggest that the landslide evolved in a multi-stage fashion. The crown cracks near the headscarp also suggest that the landslide may not be in stable state and that instability may still be ongoing;

313 This giant MTD is thus the record of a major event in the late-Quaternary of the Scotian

314 Slope and its significance was only just discovered as part of Canada's extended

315 continental shelf program under UNCLOS. Such systematic mapping programs are thus

316 vital for the evaluation of geohazards on continental margins. Further investigations of this 
317 MTD should be accomplished in order to determine how it evolved during the Holocene

318 and to evaluate whether or not it is in a stable state.

\section{Acknowledgements}

320 The authors thank the Atlantis AT22-1 and Hudson 2016-011 Phase 1 participants for their

321 help during data acquisition. Support for this project was from the Geological Survey of 322 Canada.

\section{References}

324 BAETEN, N.J., LABERG, J.S., ET AL. 2013. Morphology and origin of smaller-scale mass 325 movements on the continental slope off northern Norway. Geomorphology, 187, 326 122-134, doi: 10.1016/j.geomorph.2013.01.008.

327 CAuchon-Voyer, G., Locat, J. \& ST-Onge, G. 2008. Late-Quaternary morpho328 sedimentology and submarine mass movements of the Betsiamites area, Lower St. Lawrence Estuary, Quebec, Canada. Marine Geology, 251, 233-252, doi: 10.1016/j.margeo.2008.03.003.

DEPTUCK, M. \& CAMPBELL, D.C. 2012. Widespread erosion and mass failure from the 51 Ma Montagnais marine bolide impact off southwestern Nova Scotia, Canada. Canadian Journal of Earth Sciences, 49, 1567-1594, doi: 10.1139/e2012-070.

Frey-Martinez, J., CARTwright, J. \& JAmes, D. 2006. Frontally confined versus frontally emergent submarine landslides: A 3D seismic characterisation. Marine and Petroleum Geology, 23, 585-604, doi: 10.1016/j.marpetgeo.2006.04.002.

HAMPTON, M.A., LeE, H.J. \& LocAT, J. 1996. Submarine landslides. Reviews of Geophysics, 34, 33-59, doi: 10.1029/95rg03287.

Hughes-Clarke, J.E. 1988. The Geological Record of the 1929 Grand Banks", Earthquake and Its Relevance to Deep-Sea Clastic Sedimentation. Dalhousie University.

HuhnerbaCH, V. \& MASson, D.G. 2004. Landslides in the North Atlantic and its adjacent seas : an analysis of their morphology, setting and behaviour. Marine 
Geology, 213, 343-362, doi: 10.1016/j.margeo.2004.10.013.

JenNer, K.A., PiPer, D.J.W., CAMPBell, D.C. \& Mosher, D.C. 2007. Lithofacies and origin of late Quaternary mass transport deposits in submarine canyons, central

MazzotTI, S. 2007. Geodynamic models for earthquake studies in intraplate North

Kane, I.A., McCaffrey, W.D., Peakall, J. \& Kneller, B.C. 2010. Submarine channel levee shape and sediment waves from physical experiments. Sedimentary Geology, 223, 75-85, doi: 10.1016/j.sedgeo.2009.11.001.

KLAUCKe, I., Hesse, R. \& Ryan, W.B.F. 1997. Flow parameters of turbidity currents in a low-sinuosity giant deep-sea channel. Sedimentology, 44, 1093-1102, doi: 10.1111/j.1365-3091.1997.tb02180.x.

Laberg, J.S. \& CAmerlenghi, A. 2008. The Significance of Contourites for Submarine Slope Stability. In: Rebesco, M. \& Camerlenghi, A. (eds) Contourites. Elsevier, 537-556., doi: 10.1016/S0070-4571(08)10025-5.

LEE, H., LOCAT, J., ET AL. 2007. Submarine mass movements on continental margins. In: Nittrouer, C. A., Austin Jr, J. A., Field, M., Kravitz, J. H., Syvitski, J. P. M. \& Wiberg, P. L. (eds) Continental Margin Sedimentation: From Sediment Transport to Sequence Stratigraphy. Malden, MA, Wiley, Book Section, 213-274., doi: $10.1002 / 9781444304398$.

LEE, H.J. 2009. Timing of occurrence of large submarine landslides on the Atlantic Ocean margin. Marine Geology, 264, 53-64, doi: 10.1016/j.margeo.2008.09.009.

LI, W., ALVES, T.M., ET AL. 2016. Morphology, age and sediment dynamics of the upper headwall of the Sahara Slide Complex, Northwest Africa: Evidence for a large Late Holocene failure. Marine Geology, doi: http://dx.doi.org/10.1016/j.margeo.2016.11.013. America. The Geological Society of America, Special Paper, 425, 17-33, doi: 10.1130/2007.2425(02). 
372 McAdoo, B.G., Pratson, L.F. \& Orange, D.L. 2000. Submarine landslide

373 geomorphology, US continental slope. Marine Geology, 169, 103-136.

374 Micallef, A., Masson, D.G., Berndt, C. \& Stow, D.A. V. 2007. Morphology and

375 mechanics of submarine spreading: A case study from the Storegga Slide. Journal of

376 Geophysical Research: Earth Surface, 112, 1-21, doi: 10.1029/2006JF000739.

377 Migeon, S., Savoye, B., Zanella, E., Mulder, T., Faugeres, J.-C. \& Weber, O.

378 2001a. Detailed seismic-refection and sedimentary study of turbidite sedimentwaves

379 on the Var Sedimentary Ridge (SE France): significance forsediment transport and

380 deposition and for the mechanisms ofsediment-wave construction. Marine And

$381 \quad$ Petroleum Geology, 18, 179-208.

382 Migeon, S., Savoye, B., Zanella, E., Mulder, T., Faugères, J.C. \& Weber, O.

383 2001b. Detailed seismic-reflection and sedimentary study of turbidite sediment

$384 \quad$ waves on the Var Sedimentary Ridge (SE France): significance for sediment

385 transport and deposition and for the mechanisms of sediment-wave construction.

$386 \quad$ Marine and Petroleum Geology, 18, 179-206.

387 Mosher, D.C., PiPer, D.J.W., Calvin CAMpbell, D. \& Jenner, K.A. 2004. Near-

388 surface geology and sediment-failure geohazards of the central Scotian Slope. AAPG

389 Bulletin, 88, 703-723, doi: 10.1306/01260403084.

390 PIPER, D.J.W. 1991. Surficial geology and physical properties 6: deep water surficial 391 geology. In: Scotian Shelf. 121., doi: 10.4095/210698.

392 PIPER, D.J.W. 2005. Late Cenozoic evolution of the continental margin of eastern 393 Canada. Norwegian Journal of Geology, 85, 305-318.

394 PIPER, D.J.W. \& AKSU, A.E. 1987. The source and origin of the 1929 grand banks 395 turbidity current inferred from sediment budgets. Geo-Marine Letters, 7, 177-182.

396 PIPER, D.J.W. \& INGRAM, S. 2003. Geological Survey of Canada Major Quaternary 397 sediment failures on the east Scotian Rise, eastern Canada. Current Research $398 \quad$ Geological Survey of Canada, 1-7.

399 PIPER, D.J.W. \& MCCALL, C. 2003. A Synthesis of the Distribution of Submarine Mass 
Journal: Geological Society of London Special Publications 477

https://doi.org/10.1144/SP477.14

400

401

402

403

404

405

406

407

408

409

410

411

412

413

414

415

416

417

418

419

420

421

422

423

424

425

426

427

Movements on the Eastern Canadian Margin. In: Locat, J. \& Mienert, J. (eds)

Submarine Mass Movements and Their Consequences. Springer Netherlands, 291298., doi: 10.1007/978-94-010-0093-2.

PIPER, D.J.W., FARRE, J.A. \& SHOR, A. 1985. Late Quaternary slumps and debris flows on the Scotian Slope. Geological Society of America Bulletin, 96, 1508-1517.

PIPER, D.J.W., COCHONAT, P. \& MORRISON, M.L. 1999. The sequence of events around the epicentre of the 1929 Grand Banks earthquake: initiation of debris flows and turbidity current inferred from sidescan sonar. Sedimentology, 46, 79-97.

PiPer, D.J.W., Mosher, D.C., Gauley, B.J., Jenner, K. \& CAMPBell, D.C. 2003. The chronology and recurrence of submarine mass movements on the continental slope off southeastern Canada. In: Locat, J. \& Mienert, J. (eds) Submarine Mass Movements and Their Consequences, Advances in Natural and Technological Hazards Research. Springer Netherlands, 299-306.

PIPER, D.J.W., Mosher, D.C. \& CAMPBELl, D.C. 2012. Controls on the distribution of major types of submarine landslides. In: Clague, J. J. \& Stead, D. (eds) Landslides: Types, Mechanisms and Modeling. Cambridge University Press, 95-107.

PiPER, D.J.W., CAMPBell, D.C. \& MosheR, D.C. 2016. Mid-latitude complex troughmouth fans, Laurentian and Northeast fans, eastern Canada. In: Dowdeswell, J. A., Canals, M., Jakobsson, M., Todd, B. J., Dowdeswell, E. . \& Hogan, K. A. (eds) Atlas of Submarine Glacial Landforms: Modern, Quaternary and Ancient. London, Geological Society, 363-364., doi: 10.1144/M46.93.

SKENE, K.I. \& PIPER, D.J.W. 2003. Late Quaternary stratigraphy of Laurentian Fan: A record of events off the eastern Canadian continental margin during the last deglacial period. Quaternary International, 99-100, 135-152, doi: 10.1016/S10406182(02)00116-7.

SKENE, K.I., PIPER, D.J.W. \& HILl, P.R. 2002. Quantitative analysis of variations in depositional sequence thickness from submarine channel levees. Sedimentology, 49, 1411-1430. 
Journal: Geological Society of London Special Publications 477

https://doi.org/10.1144/SP477.14

428 Smith, D.P., Ruiz, G., KviteK, R. \& IAmPiEtro, P.J. 2005. Semiannual patterns of

429 erosion and deposition in upper Monterey Canyon from serial multibeam

$430 \quad$ bathymetry. Geological Society of America Bulletin, 117, 1123-1133, doi:

$431 \quad 10.1130 / \mathrm{b} 25510.1$.

432 ToDD, B.J. 2016. The Laurentian Channel : a major cross-shelf trough in Atlantic

433 Canada. In: Dowdeswell, J. A., Canals, M., Jakobsson, M., Todd, B. J., Dowdeswell,

434 E. . \& Hogan, K. A. (eds) Atlas of Submarine Glacial Landforms: Modern,

435 Quaternary and Ancient. London, Geological Society, 161-162.

436

437 


\section{$438 \quad$ Figures}

439 Figure 1: Location of Laurentian Fan and the Western Levee of Western Valley (black 440 frame) off of the eastern Canadian continental margin. EV: Eastern Valley, CV: Central 441 Valley, WV: Western Valley

442 Figure 2: GI-gun seismic profiles illustrating A) the surficial MTD in relation to the 443 unnamed channel and a large 150 ka MTD (MTD-D); B) the stratified levee deposits and 444 the occurrence of mass-transport deposits (MTD). Red polygons represent buried MTDs.

445 Figure 3: Multibeam bathymetry $(60 \mathrm{~m}$ grid) of the Western Levee of Western Valley 446 illustrating the spillover channel and the large mass-transport deposit (WLWV MTD).

447 Figure 4: Sub-bottom profiles $(3.5 \mathrm{kHz})$ of the two main acoustic facies observed in the 448 upper stratigraphic succession of the levee: A) high-amplitude reflections with occasional 449 small mass-transport deposits (MTD) and B) chaotic to incoherent acoustic facies 450 representing the major WLWV MTD affecting a large part of the levee.

451 Figure 5: Multibeam bathymetry of the upper levee illustrating the different 452 geomorphological features present, including ridges and troughs, blocky debris zone, 453 crown cracks and lobe superposition.

454 Figure 6: Backscatter map of the Western Levee of Western Valley illustrating the higher 455 intensity over the mass-transport deposit and flow lineations.

456 Figure 7: Huntec and sub-bottom profiles $(3.5 \mathrm{kHz})$ of the Western levee illustrating A) 457 erosion of the glide plane and emergence at the toe of the MTD and B) retrogressive 458 headwalls in the upper parts of the levee. Red polygon represents a buried MTD. 
Journal: Geological Society of London Special Publications 477

https://doi.org/10.1144/SP477.14

460 Figure 1

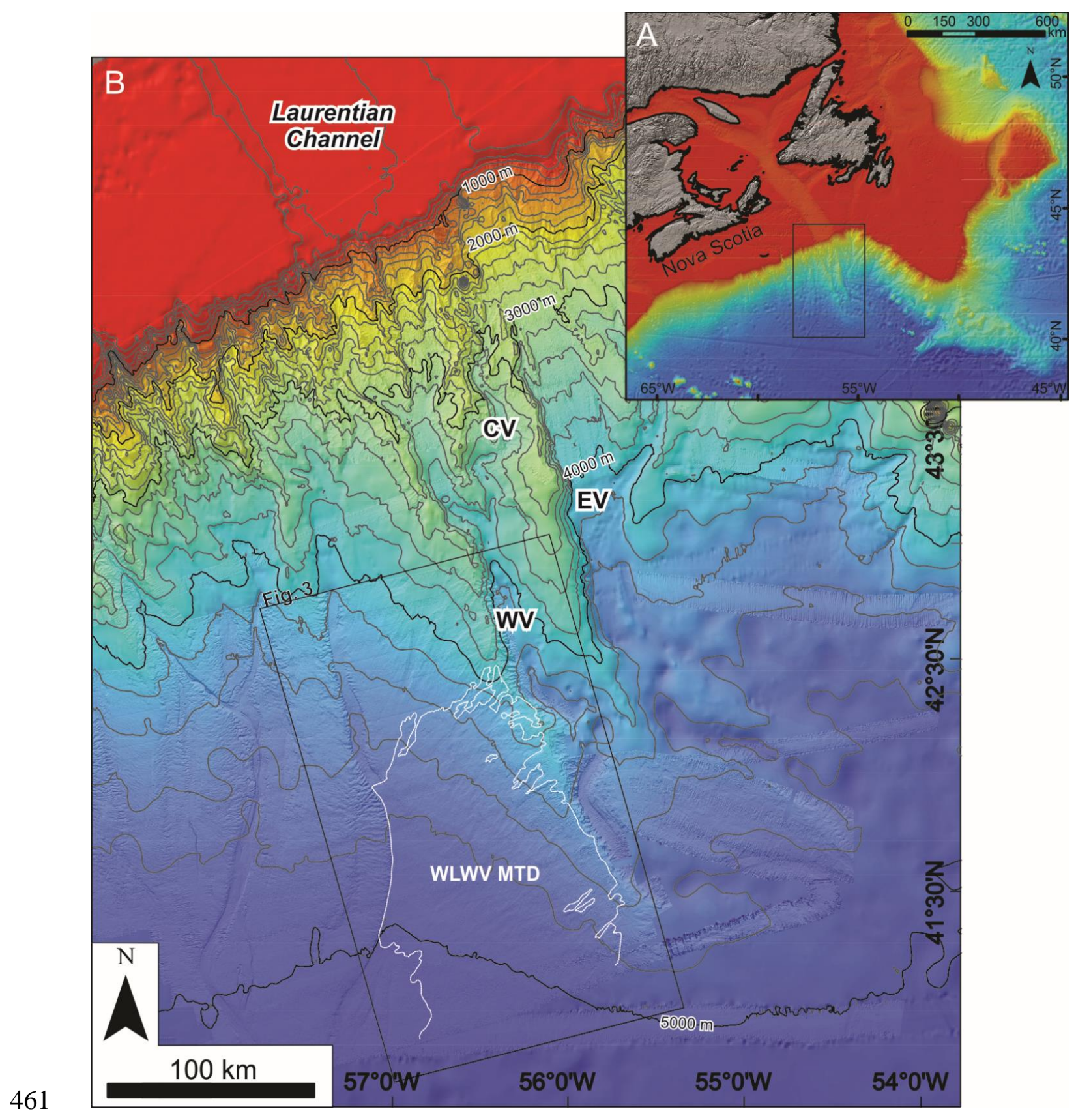

462 


\section{Journal: Geological Society of London Special Publications 477}

https://doi.org/10.1144/SP477.14

\section{Figure 2}
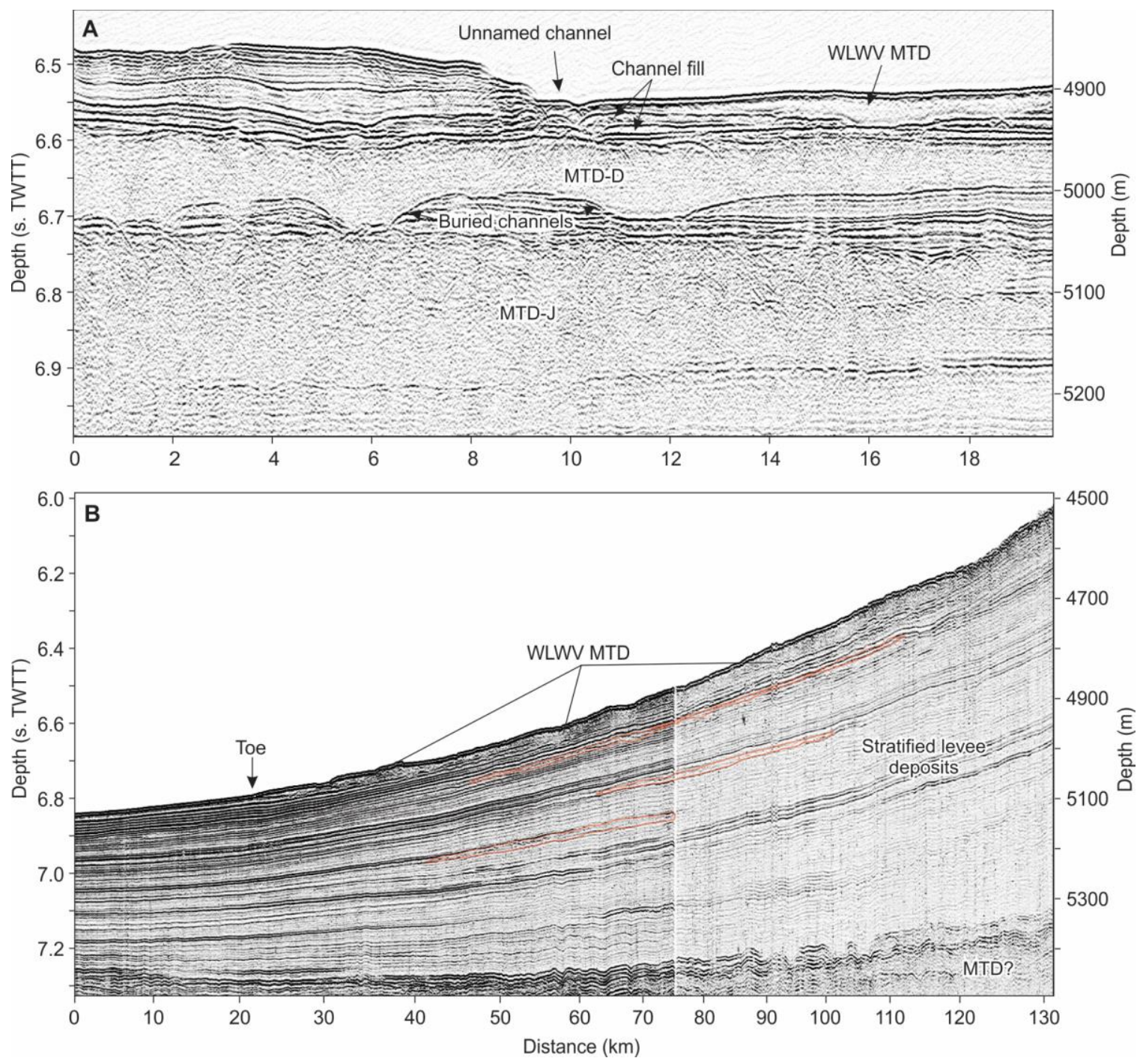
Journal: Geological Society of London Special Publications 477

https://doi.org/10.1144/SP477.14

466 Figure 3

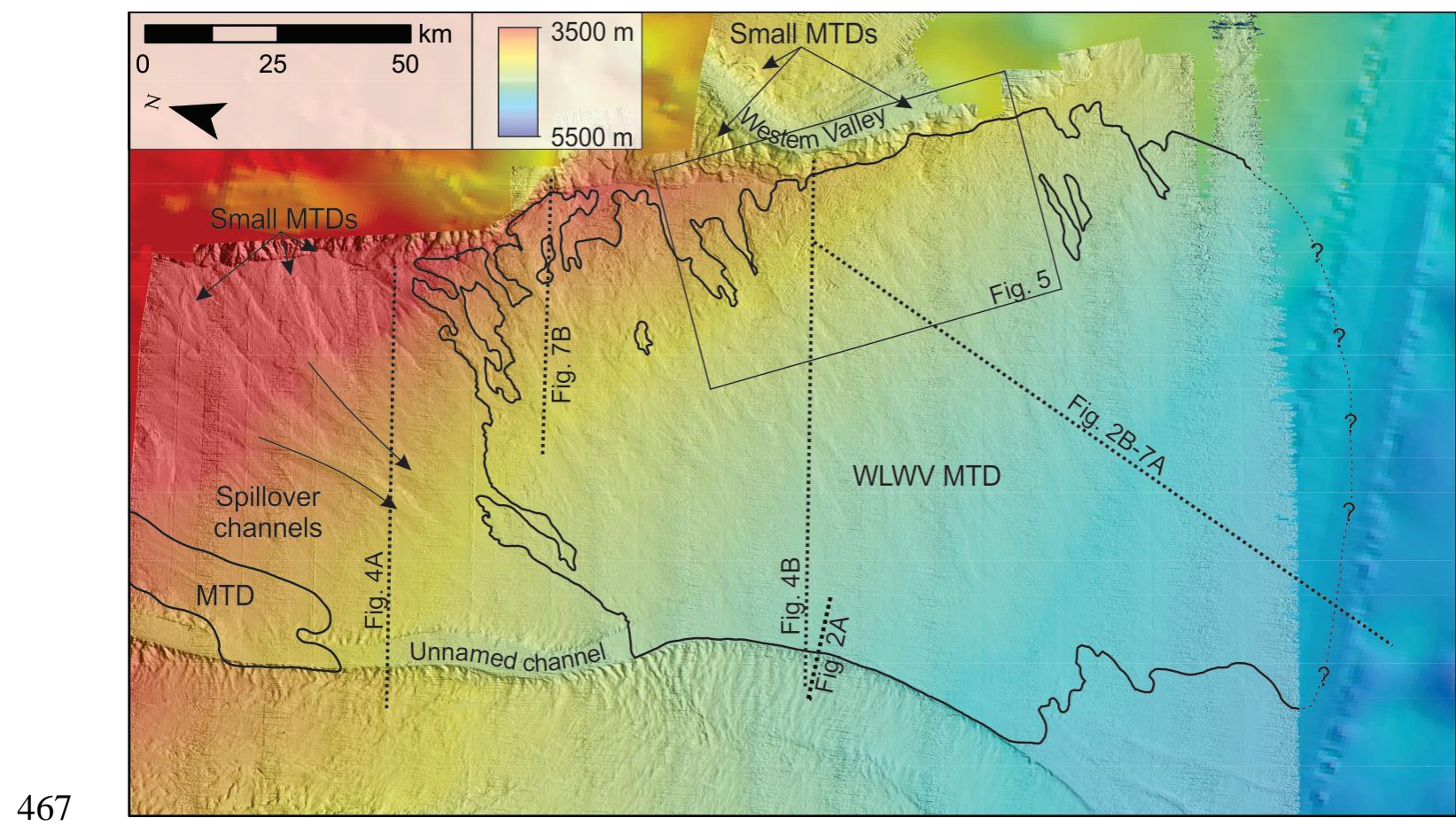

468 
Journal: Geological Society of London Special Publications 477

https://doi.org/10.1144/SP477.14

469 Figure 4

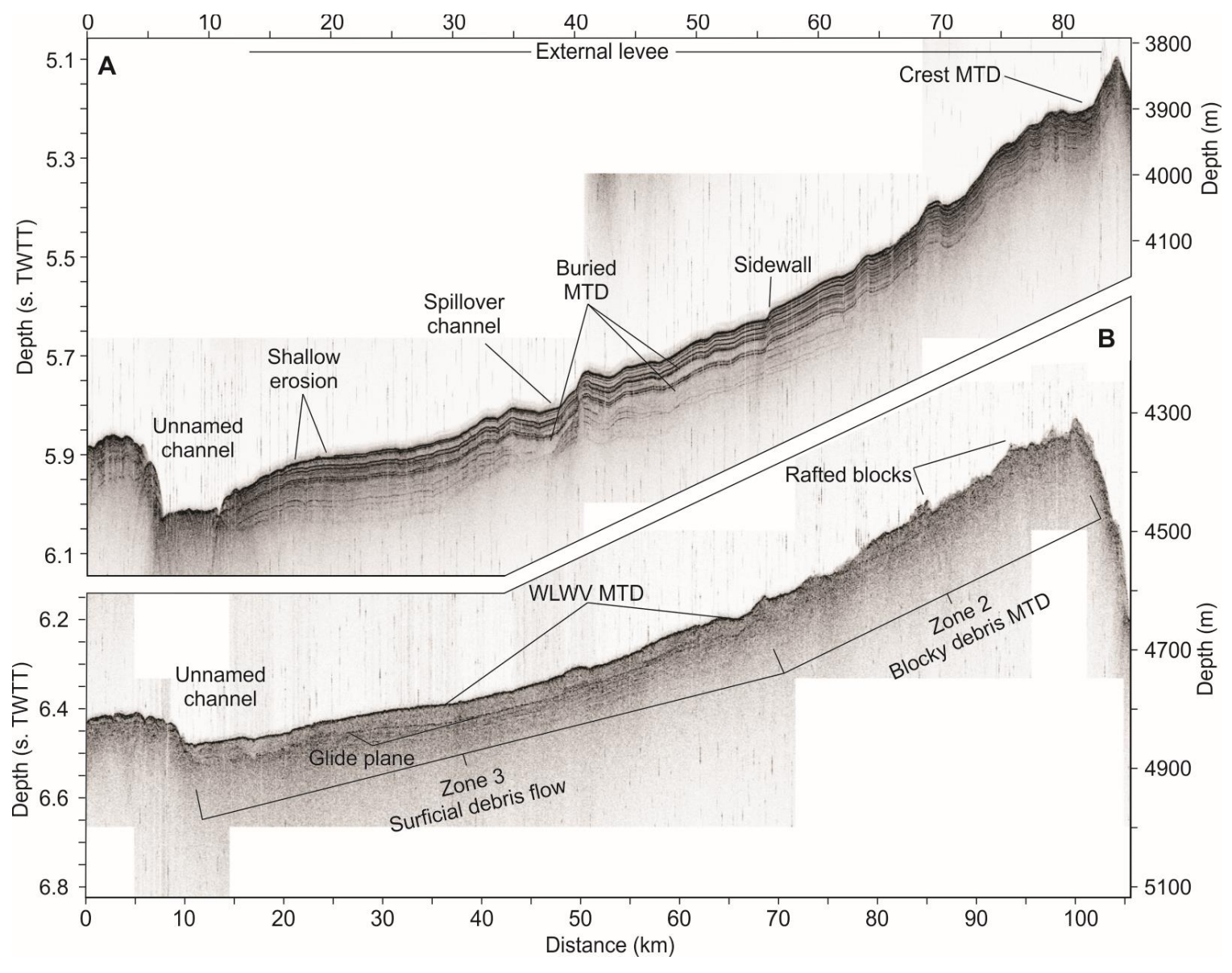

471 
Journal: Geological Society of London Special Publications 477

https://doi.org/10.1144/SP477.14

472 Figure 5

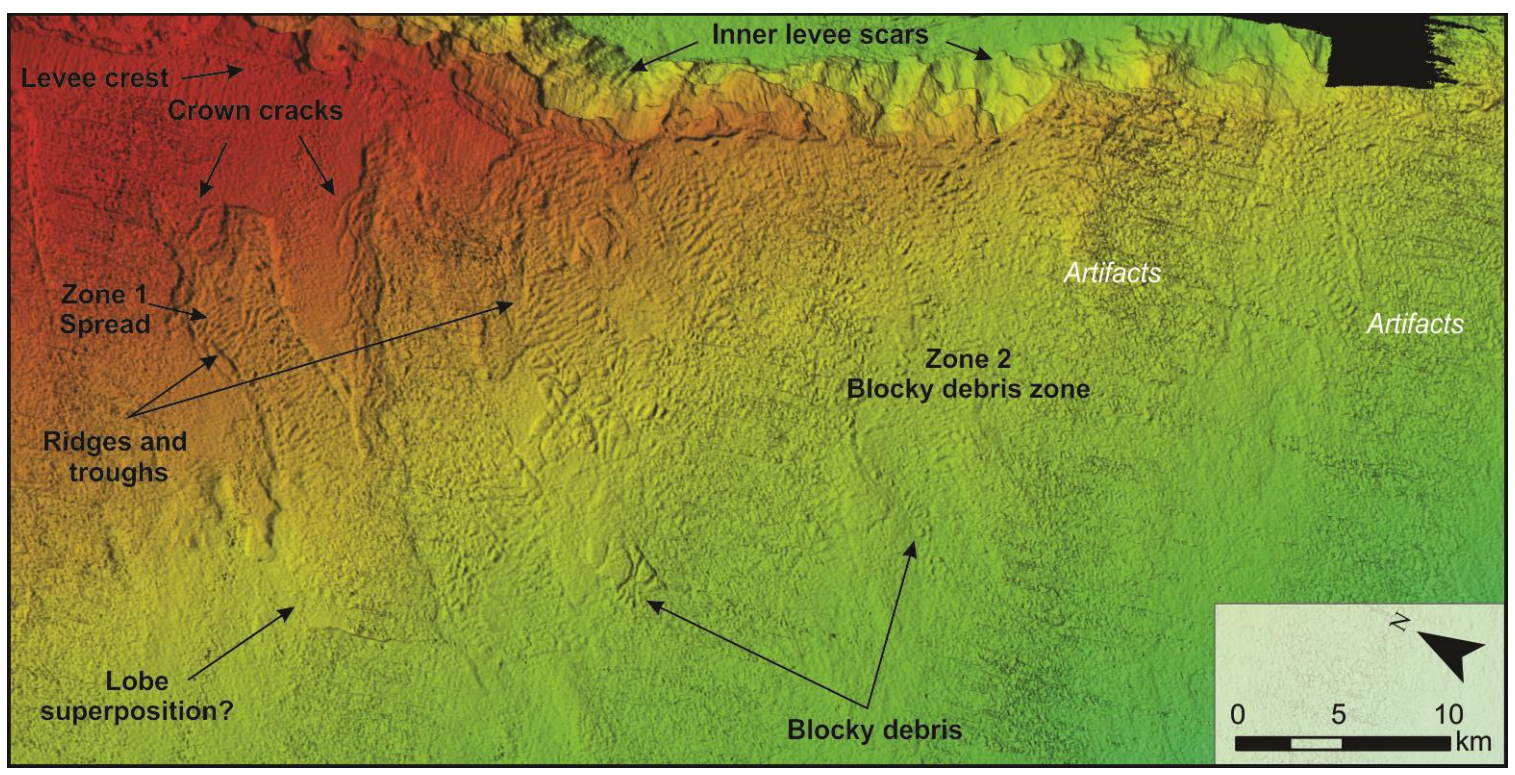

474 
Journal: Geological Society of London Special Publications 477

https://doi.org/10.1144/SP477.14

$475 \quad$ Figure 6

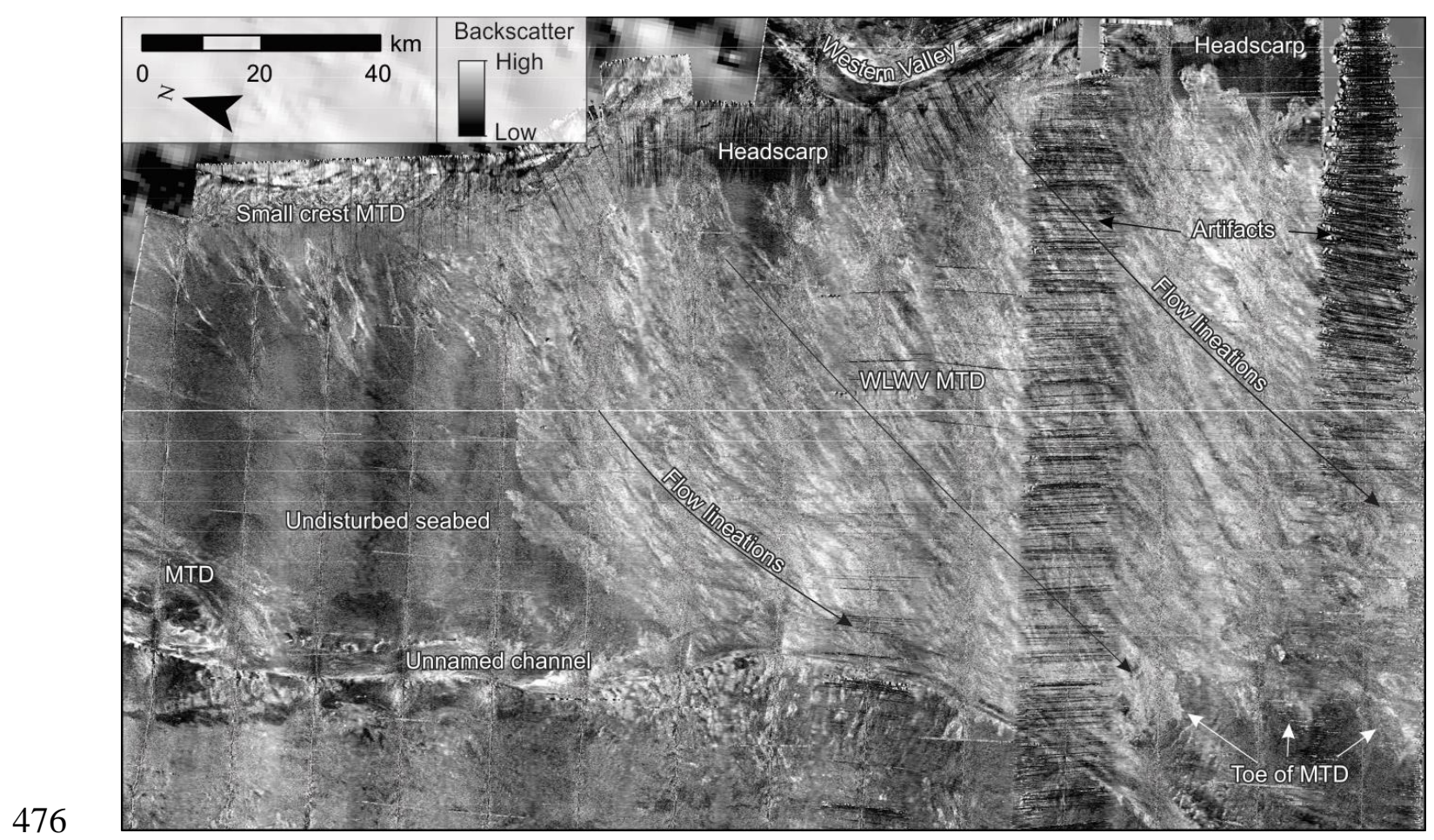

477 
Journal: Geological Society of London Special Publications 477

https://doi.org/10.1144/SP477.14

478 Figure 7

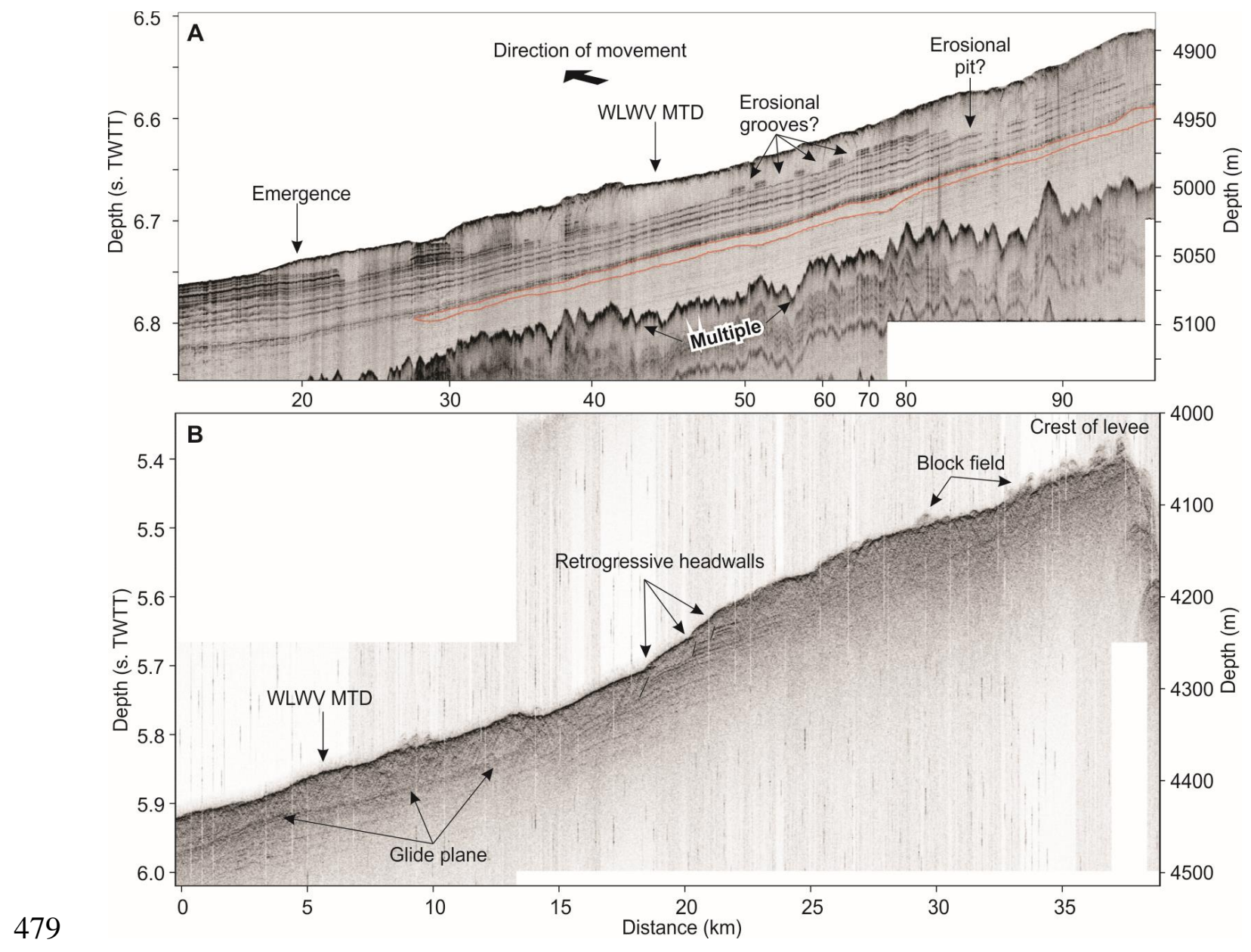

